ks. Stanisław Wronka

\title{
Transliteracja i transkrypcja alfabetu greckiego
}

Czcionki greckiej używa się o wiele częściej w publikacjach niż czcionki hebrajskiej, ale niekiedy trzeba i ją oddać alfabetem łacińskim. Nie jest to tak trudne, jak w wypadku języka hebrajskiego, jednak czasem mogą się rodzić wątpliwości, tym bardziej że istnieją różne sposoby takiej konwersji. Podobnie więc jak to zrobiliśmy w wypadku klasycznego języka hebrajskie$\mathrm{go}^{1}$, pragniemy teraz zaproponować pewien system transliteracji i transkrypcji greki starożytnej, aby ułatwić zapisywanie tekstów greckich alfabetem łacińskim. W podręcznikach i gramatykach do greki na ogół tę kwestię się pomija ${ }^{2}$. Propozycja ta mogłaby stanowić punkt wyjścia do dyskusji, aby uzgodnić pewien wspólny system i używać go potem w naszych pracach.

Mówimy o transliteracji i transkrypcji, bo mimo że dość powszechnie używa się tych terminów zamiennie, nie oznaczają one dokładnie tego samego. Transliteracja oddaje precyzyjnie znak graficzny każdej litery, nie uwzględniając jej dźwięku, natomiast transkrypcja jest zapisem fonetycznym, oddaje wymowę poszczególnych liter ${ }^{3}$. W artykule przedstawimy najpierw tabele ukazujące, w jaki sposób transliterujemy i transkrybujemy znaki greckie, a potem spróbujemy wyjaśnić nasze stanowisko na tle innych rozwiązań. Na koniec pokażemy na przykładach, jak funkcjonuje proponowany przez nas system.

${ }^{1}$ Por. S. WronkA, Transliteracja i transkrypcja alfabetu hebrajskiego, , Ruch Biblijny i Liturgiczny" 1 (2004), s. 45-58.

${ }^{2}$ Wyjątkowo próbkę transliteracji podaje E. G. JAY, New Testament Greek. An Introductory Grammar, London 1981, s. 12-13.

${ }^{3}$ Por. S. Wronka, Transliteracja i transkrypcja alfabetu hebrajskiego, art. cyt., s. 45-46. 


\section{System transliteracji i transkrypcji}

\section{ALFABET GRECKI}

\begin{tabular}{|c|c|c|c|c|c|c|c|}
\hline \multicolumn{2}{|c|}{ Litera } & \multirow{2}{*}{$\begin{array}{l}\text { Nazwa } \\
\text { álpha }\end{array}$} & \multicolumn{2}{|c|}{ Transliteracja } & \multicolumn{2}{|c|}{ Transkrypcja } & \multirow{2}{*}{$\begin{array}{l}\text { Wartość liczbowa } \\
1\end{array}$} \\
\hline $\mathrm{A}$ & $\alpha$ & & $A$ & $a$ & $A$ & $a$ & \\
\hline B & $\beta$ & bêta & $B$ & $b$ & $B$ & $b$ & 2 \\
\hline$\Gamma$ & $\gamma$ & gámma & $G$ & $g$ & $G$ & $g(n)^{4}$ & 3 \\
\hline$\Delta$ & $\delta$ & délta & $D$ & $d$ & $D$ & $d$ & 4 \\
\hline $\mathrm{E}$ & $\epsilon$ & è psilón & $E$ & $e$ & $E$ & $e$ & 5 \\
\hline $\mathrm{Z}$ & $\zeta$ & zêta & $D z$ & $d z$ & $D z$ & $d z$ & 7 \\
\hline $\mathrm{H}$ & $\eta$ & êta & $\bar{E}$ & $\bar{e}$ & $E$ & $e$ & 8 \\
\hline$\Theta$ & $\theta$ & thêta & $T h$ & th & $T h$ & th & 9 \\
\hline I & $\iota$ & iôta & $I$ & $i$ & $I$ & $i(j)^{5}$ & 10 \\
\hline K & $\kappa$ & káppa & $K$ & $k$ & $K$ & $k$ & 20 \\
\hline$\Lambda$ & $\lambda$ & lámbda & $L$ & $l$ & $L$ & $l$ & 30 \\
\hline M & $\mu$ & $m \hat{y}$ & $M$ & $m$ & $M$ & $m$ & 40 \\
\hline $\mathrm{N}$ & $v$ & $n \hat{y}$ & $N$ & $n$ & $N$ & $n$ & 50 \\
\hline$\Xi$ & $\xi$ & $x \hat{\imath}(x e \hat{\imath})$ & $X$ & $x$ & $K s$ & $k s$ & 60 \\
\hline $\mathrm{O}$ & o & ò mikrón & $O$ & $O$ & $O$ & $o$ & 70 \\
\hline$\Pi$ & $\pi$ & $p \hat{\imath}(p e \hat{\imath})$ & $P$ & $p$ & $P$ & $p$ & 80 \\
\hline $\mathrm{P}$ & $\rho$ & $r h \hat{o}$ & $R$ & $r$ & $R$ & $r$ & 100 \\
\hline$\Sigma$ & $\sigma \varsigma$ & sígma & $S$ & $s$ & $S$ & $s$ & 200 \\
\hline $\mathrm{T}$ & $\tau$ & $t a \hat{u}$ & $T$ & $t$ & $T$ & $t$ & 300 \\
\hline $\mathrm{Y}$ & u & ŷpsilón & $Y$ & $y(u)$ & $Y$ & $y(t)^{6}$ & 400 \\
\hline$\Phi$ & $\phi$ & phî (phêे) & $P h$ & $p h$ & $F$ & $f$ & 500 \\
\hline $\mathrm{X}$ & $\chi$ & $\operatorname{ch} \hat{\imath}(\operatorname{che} \hat{\imath})$ & Ch & ch & Ch & $c h$ & 600 \\
\hline$\Psi$ & $\psi$ & psî $(p s e \hat{\imath})$ & $P S$ & $p s$ & $P s$ & $p s$ & 700 \\
\hline$\Omega$ & $\omega$ & ô méga & $\bar{O}$ & $\bar{O}$ & $O$ & $O$ & 800 \\
\hline
\end{tabular}

\begin{tabular}{|c|c|c|c|}
\hline \multicolumn{2}{|c|}{ SAMOGŁOSKI ZLOŻONE (DYFTONGI) } & Transliteracja & Transkrypcja \\
\hline właściwe & $\alpha \iota$ & $a i$ & $a j$ \\
\hline & $\epsilon \mathrm{L}$ & $e i$ & ej \\
\hline & $\mathrm{Ol}$ & $o i$ & $o j$ \\
\hline & ul & $y i$ & $y j$ \\
\hline & $\alpha u$ & $a u$ & at \\
\hline & $\epsilon U$ & $e u$ & et \\
\hline & $\eta \cup$ & $\bar{e} u$ & et \\
\hline & $\mathrm{Al}$ & $A i$ & $A j$ \\
\hline
\end{tabular}

${ }^{4}$ Jak $n$ czyta się $\gamma$ przed $\gamma, \kappa, \xi, \chi$.

${ }^{5}$ Tylko w dyftongch ı jest czytane jak $j$.

${ }^{6}$ Gdy u znajduje się w dyftongach na drugim miejscu ( $\left.\alpha \mathrm{v}, \epsilon \mathrm{v}, \eta \mathrm{\eta}, \mathrm{ov}\right)$, transliterujemy go przez $u$, a transkrybujemy przez $\nmid z$ wyjątkiem ostatniej dwugłoski ou . 
niewłaściwe

iota subscriptum
iota adscriptum

iota subscriptum
iota adscriptum

PRZYDECHY

słaby

mocny

niski

przeciągły

\section{AKCENTY}

wysoki

Trema

Apostrof

Koronis

Interpunkcja

ou
$\alpha$
$\eta$
$\omega$
Aı

ou

$a_{i}$

$\bar{e}_{i}$

$\bar{O}_{i}$

$A_{i}$

$u$

a

e

o

A

$\begin{array}{lll}\dot{\alpha} & a & a \\ \text { 'A } & A & A \\ \alpha i & a i & a j \\ \text { 'Aı } & A_{i} & A \\ \mathrm{~A} i & A i & A j \\ \dot{\alpha} & h a & h a \\ \alpha i & h a i & h a j \\ \text { 'A } & H a i & H a \\ \mathrm{Ai} & H a i & H a j \\ \dot{\rho} & r h & r \\ \text { 'P } & R h & R \\ -\rho \dot{\rho}- & -r r h- & -r r-\end{array}$




\section{Objaśnienia}

Małe litery $€$ i $\theta$ mogą mieć też inną formę: $\varepsilon$, 邓; nie ma to znaczenia dla ich transliteracji i transkrypcji, oddajemy je również przez $e$ i th. Końcowa formę $\varsigma$ oznaczamy tak samo przez $s$, jak formę występującą na początku

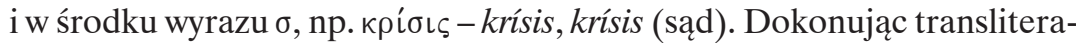

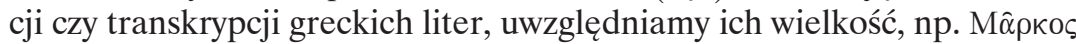
- Mârkos, Márkos (Marek). Litery i liczby w transliteracji i transkrypcji piszemy kursywą.

\section{SPÓŁGŁOSKI}

Spółgłoskę $\gamma$ wymawiamy przed $\gamma, \kappa, \xi, \chi$ jak gardłowe $n$, dlatego tak piszemy ją w transkrypcji, ale w transliteracji zostawiamy $g$, np. ״ै $\gamma \gamma \in \lambda o \varsigma$

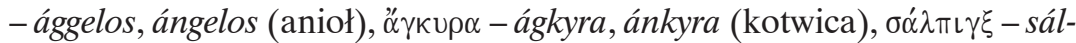

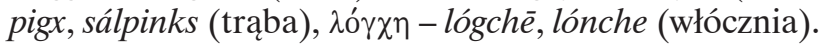

Literę $\zeta$ transliterujmy i transkrybujemy przez $d z$, bo jest to spółgłoska podwójna $(\delta \sigma)$ obok $\xi(\kappa \sigma)$ i $\psi(\pi \sigma)$, które oddajemy odpowiednio przez

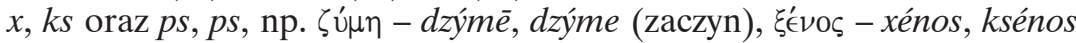
(obcy), $\psi \in \dot{\sigma} \sigma \eta \varsigma$ - pseústēs, psétstes (kłamca). Transliteracja, a tym bardziej transkrypcja $\zeta$ przy pomocy prostego $z$ wydaje się mniej odpowiednia, np. zýmē, zýme . Spółgłoskę $\xi$ można by też transliterować przez ks, np. ksénos, ksénos, jednak łacińskie $x$ przyjęło się powszechnie.

Spółgłoska $\theta$ jest transliterowana i transkrybowana przez th, np. $\theta^{\prime} \in \omega$ - thélō, thélo (chcę), ponieważ należy do spółgłosek aspirowanych razem z $\phi$ $(p h)$ i $\chi(k h)$. Język łaciński nie znał tych spółgłosek, dlatego ф wymawiamy dziś jak $f$, a $\chi$ jak $c h^{8}$. Z tego też powodu $c h$ jest powszechnie używane zarówno w transliteracji, jak i transkrypcji, a $f \mathrm{w}$ transkrypcji, np. $\chi \alpha i \rho \omega-c h a i ́ r o ̄$, chájro (cieszę się), фı $\lambda \epsilon ́ \omega-$ philéo, filéo (kocham). Niekiedy spotykamy $f$ również w transliteracji, np. filéo, filéo ${ }^{9}$. Oddawanie $\chi$ przez $h$ jest bardzo rzadkie, np. haírō, hájro ${ }^{10}$, gdyż zazwyczaj litery tej używa się na oznaczenie

${ }^{7}$ Taki zapis można spotkać np. w: Słownik ortograficzny języka polskiego wraz z zasadami pisowni i interpunkcji, red. M. SzYMCZAK, Warszawa 1976, s. 132, który przytacza system oddawania liter greckich przy pomocy alfabetu łacińskiego zalecony w 1959 roku przez International Standard Organistion; E. G. JAY, New Testament Greek, s. 2; A. VANHOYE, La lettera ai Galati, seconda parte, Roma 1985.

${ }^{8}$ Por. M. Auerbach, M. Golias, Gramatyka grecka, Warszawa ${ }^{3} 1962$, s. 5. Ch wymawiamy mocniej niż $h$, odwrotnie niż w niektórych regionach Polski przed II wojną światową, gdzie $h$ miało mocniejszą wymowę; por. S. WronKA, Transliteracja i transkrypcja alfabetu hebrajskiego, art. cyt., s. 49.

${ }^{9}$ Por. np. Stownik ortograficzny języka polskiego, dz. cyt., s. 132.

${ }^{10}$ Czyni tak np. Stownik ortograficzny języka polskiego, dz. cyt., s. 132. 
przydechu mocnego. Niektórzy transkrybują spółgłoski $\phi$ i $\chi$ przez $p h$ i $k h$, zgodnie z ich wymową w grece klasycznej, np. philéo, khájro ${ }^{11}$.

Litera $\sigma$ jest wymawiana czasem jak $z$. Ma to np. miejsce, gdy spółgłoska ta znajduje się pomiędzy samogłoskami (nie dotyczy to jednak wypadku, gdy przed $\sigma$ występuje augment) lub przed $\beta, \mu$. Niektórzy zaznaczają to

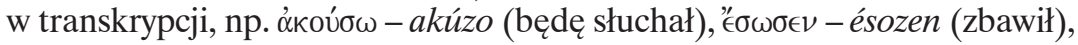

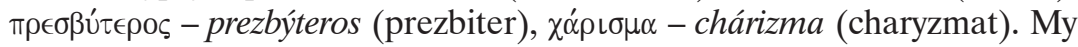
piszemy konsekwentnie s: akúso, ésosen, presbýteros, chárisma.

\section{SAMOGŁOSKI}

$\mathrm{H}$ i $\omega$ są zawsze długie, dlatego transliterujemy te samogłoski przez $\bar{e}$, $\bar{o}$, aby odróżnić je od $€$ i o, które są zawsze krótkie $(e, o)$. W wymowie nie słychać tej różnicy, więc będziemy transkrybować tak samo: $e, o$. Pozostałe samogłoski: $\alpha$, ı, v mogą być długie lub krótkie; nie zaznaczamy tego ani

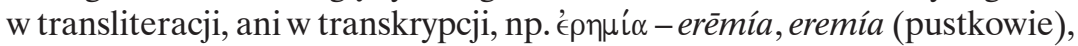

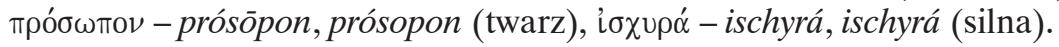

I jest samogłoską wymawianą zawsze, gdy występuje samodzielnie, jak $i$,

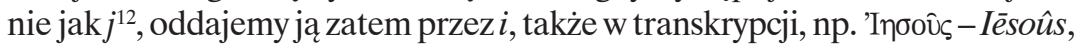
Iesús (Jezus). Jedynie w dyftongach ( $\alpha \mathrm{\iota}, \epsilon \mathrm{l}, \mathrm{ol}, \mathrm{v} \iota)$ samogłoska ta brzmi jak $j$, dlatego transkrybujemy ją wtedy przez $j(a j, e j, o j, y j)$, ale w transliteracji

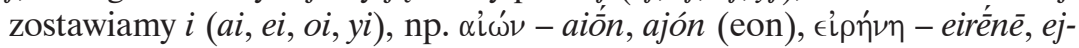
réne (pokój), oîkos - ô̂kos, ójkos (dom), viós - hyiós, hyjós (syn). Taki zapis transkrypcyjny jest podyktowany tym, że w języku polskim zbitki: ai, ei, oi, yi wymawia się inaczej: Kain, koleina, boisko, wyimaginować. Gdy akcent pada na ı (i), słyszymy wówczas $i j$, nie zaznaczamy jednak tego w transliteracji ani w transkrypcji, np. Mapí -María, María (nie Marija) (Maryja) ${ }^{13}$.

Iota subscriptum występuje tylko pod samogłoskami długimi: $\alpha, \eta, \omega$, a iota adscriptum po nich, gdy pisane są dużą literą, tworząc z nimi dyftongi niewłaściwe, w których jest niewymawiane. Pomijamy je więc zupełnie w transkrypcji, natomiast w transliteracji zaznaczamy w indeksie dolnym, np. "A $\mathrm{\iota} \delta \omega-A_{i} d \bar{o}$,

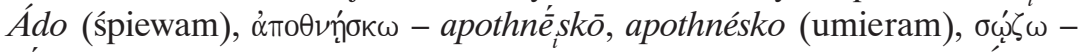
sốd $d z \bar{o}$, sódzo (zbawiam). Można by też zaznaczać je w nawiasie, np. $A(i) d \bar{o}$, apothné $(i) s k \bar{o}, s \bar{o}(i) d z \bar{O}^{14}$, lub podpisywać pod samogłoską jak w grece, np. $A_{\imath} d \bar{o}$,

${ }^{11}$ Por. M. Auerbach, M. Golias, Gramatyka grecka, s. 3; G. Szamocki, Greka Nowego Testamentu. Intensywny kurs podstawowy, Pelplin 2004, s. 18.

${ }^{12}$ Por. M. Auerbach, M. Golias, Gramatyka grecka, s. 4. Greka miała spółgłoskę $j$, która jednak zanikła; por. s. 17.

${ }^{13}$ Niekiedy można spotkać $i j \mathrm{w}$ transkrypcji, np. $\pi \alpha \lambda \iota \gamma \gamma \in \nu \in \sigma i \alpha-$ palingenesíja (odrodzenie); por. A. JANKowski, Biblijna teologia czasu, Kraków 2001, s. 30.

${ }^{14}$ Por. np. E. G. JAY, New Testament Greek, dz. cyt., s. 12-13. 


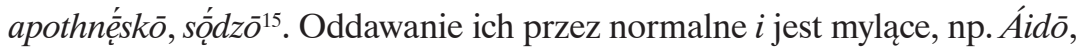
apothné́isk $\bar{o}, s o ̂ ́ i d z \bar{o}^{16}$, natomiast zupełne opuszczanie nieprecyzyjne, np. Ádō, apothnésk $\bar{o}, s o ̂ ́ d z \bar{o}^{17}$. Iota adscriptum poznać po tym, że przydech, i ewentualnie akcent, nie stoi nad nią, lecz przed poprzedzającą ją dużą samogłoską, np. "A $\delta \omega-A_{i} d \bar{o}, A ́ d o$, ale Ai̊ós - Aidós, Ajdós (godność).

Samogłoskę v transliterujemy i transkrybujemy przezy, np. kúpıos - kýrios, kýrios (pan). Jeśli występuje na drugiej pozycji w dyftongu ( $\alpha \mathrm{v}, \epsilon \mathrm{v}, \eta v, \mathrm{ov})$, oddajemy ją $\mathrm{w}$ transliteracji przez $u$, natomiast $\mathrm{w}$ transkrypcji przez $t$, $\mathrm{z}$ wyjątkiem ostatniego, niewłaściwego dyftongu ov, który cały oddajemy przez

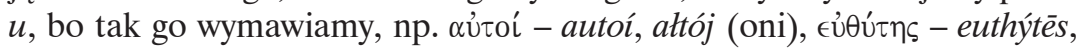

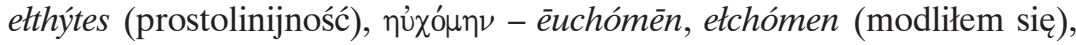
$\pi \lambda$ oûtos - ploûtos, plútos (bogactwo) ${ }^{18}$. Właściwie można by dyftongi $\alpha \mathrm{v}$, $\epsilon \mathrm{v}, \eta \cup$ transkrybować przez $a u, e u$, gdyż podobnie wymawiamy takie zbitki w wyrazach polskich pochodzenia greckiego, np. autochton, euforia (w przeciwieństwie do wyrazów rdzennie słowiańskich jak: nauka, nieuk). Jednak taki zapis pokrywałby się nam dokładnie z transkrypcją samogłosek $\alpha$ ov, €૦v,

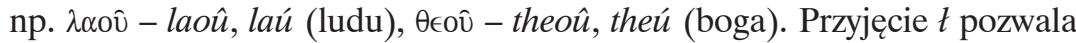
zlikwidować tę dwuznaczność w obrębie transkrypcji, bo dyftongi oddajemy przez at, et, a odrębne samogłoski przez au, eu. Nie rozwiązuje to do końca problemu, gdyż powstaje wtedy dwuznaczność pomiędzy transkrypcją a transliteracją: zapis $a u, e u$ w transkrypcji oznacza dwie odrębne samogłoski,

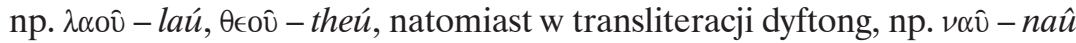
(okręcie!), $\beta \alpha \sigma \iota \lambda \in \hat{v}$ - basileû (królu!). Wydaje się, że ta druga dwuznaczność robi mniej zamieszania, dlatego decydujemy się na $t w$ transkrypcji ${ }^{19}$. Jeśli u znajduje się w dyftongu na pierwszym miejscu, oddajemy go przez $y$, np. vio $€ \epsilon \sigma i \alpha$ - hyiothesía, hyjothesía (adopcja). Wielu oznacza v zawsze przez $u$,

${ }^{15}$ Por. np. Instructions for Contributors, „Biblica” 70 (1989), s. 580. Exegetical Dictionary of the New Testament, ed. H. Balz, G. SchneIder, t. 1-3, Grand Rapids, Michigan 1990-1993, oddaje iota subscriptum przez francuski cédille (, ).

${ }^{16}$ Por. J.-N. Aletti, Lettera ai Colossesi. Introduzione, versione, commento, Bologna 1994 (Scritti delle origini cristiane 12). Przy zapisie $\bar{e} i, \bar{o} \iota$ i $\bar{E} i, \bar{O} i$ można by się domyślić, że chodzi o iota subscriptum i adscriptum, bo samogłoski $\eta \mathrm{i} \omega$ nie tworzą $\mathrm{z} \iota$ właściwego dyftongu. Dodatkowo wskazywałby na to fakt, także w odniesieniu do zapisu $a i$, że akcent nie pada na $i$ : áidō, apothnéiskō, sốidzō. Czasem jednak inna sylaba jest akcentowana i wtedy taki zapis jest dwu-

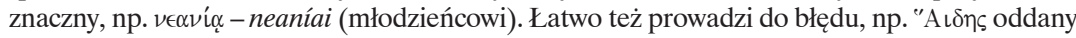
przez Haídès; por. Słownik wyrazów obcych, red. J. ToKARSKI, Warszawa 1972, s. 265.

${ }^{17}$ Por. Dizionario dei concetti biblici del Nuovo Testamento, a cura di L. CoEnen, E. BeyREUTHER, H. BIETENHARD, Bologna 21980; Słownik wyrazów obcych, dz. cyt.

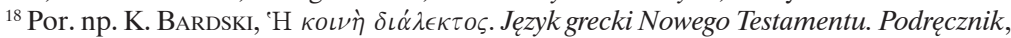
Warszawa 22000, s. 4. 82; A. i K. Konusowie, Hellenike glotta. Podręcznik do nauki języka greckiego, Warszawa 21997, s. 20; G. SzAмоскі, Greka Nowego Testamentu, dz. cyt., s. 19.

${ }^{19}$ Dla usunięcia do końca tych dwuznaczności można by ewentualnie w transkrypcji stawiać tremę nad $u$, gdy nie tworzy on dyftongu z poprzednią samogłoską, np. laü, theü. 
nawet gdy występuje samodzielnie, np. kúrios ${ }^{20}$. Niektórzy transkrybują tę samogłoskę przy pomocy niemieckiego ü, gdyż można ją tak wymawiać, np. iт́ি́ - hüpér (za) ${ }^{21}$.

\section{INNE ZNAKI}

Z przydechów, które znajdują się nad początkową samogłoską, gdy jest mała, lub przed nią, gdy jest duża (jeśli wyraz zaczyna się od dyftongu, to przydech spoczywa na drugiej samogłosce z wyjątkiem iota adscriptum), zaznaczamy zarówno w transliteracji, jak i transkrypcji tylko przydech mocny (') przy pomocy $h$, które wypowiadamy słabiej niż ch. Piszemy je zawsze przed samogłoską. Jeśli samogłoska jest mała, $h$ jest małe, natomiast

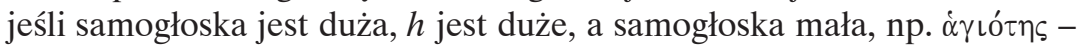

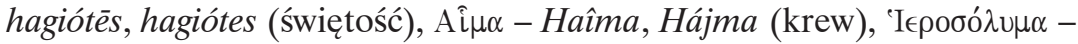
Hierosólyma, Hierosólyma (Jerozolima). Początkowe $\rho$ ma zawsze przydech mocny, który zaznaczamy po spółgłosce w postaci zawsze małego $h$ i tylko $\mathrm{w}$ transliteracji, natomiast $\mathrm{w}$ transkrypcji opuszczamy je, ponieważ nie jest

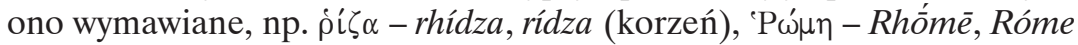
(Rzym). Dwa kolejne $\rho$ w środku wyrazu mogą być opatrzone przydechem, pierwsze słabym, a drugie mocnym. Zaznaczamy tylko ten drugi zgodnie

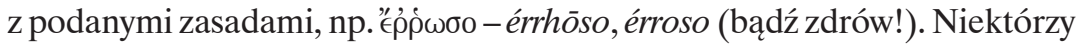
zaznaczają przydech mocny tak jak w grece, np. àgiótēs, 'Terosólyma, rídza, 'Rốmē, érrōso's2.

W transliteracji akcenty zaznaczamy nad samogłoską, w dyftongach nad drugą samogłoską, nie pierwszą ${ }^{23}$, rozróżniając akcent wysoki, niski i przeciągły. W transkrypcji upraszczamy i piszemy nad samogłoską zawsze akcent

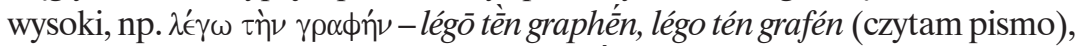

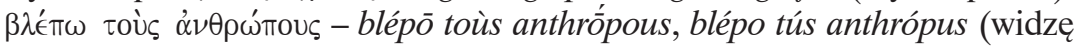
ludzi), $\alpha \gamma \alpha \theta$ ò $€ \hat{\imath}$-agathòs ề, agathós éj (dobry jesteś) ${ }^{24}$. Gdy samogłoski ē i $\bar{o}$ mają akcent przeciągły, wystarczy napisać $\hat{e}, \hat{o}$, wiadomo bowiem, że chodzi o samogłoski długie, ponieważ akcent przeciagły może spoczywać tylko na takich samogłoskach, np. $\gamma \hat{\eta}-g \hat{e}$, gé (ziemia), $\sigma \hat{\omega} \mu \alpha$ - sôma, sóma (ciało).

${ }^{20}$ Por. np. E. G. JAY, New Testament Greek, dz. cyt., s. 12-13.

${ }^{21}$ Por. K. BARDSKI, Język grecki Nowego Testamentu, dz. cyt., s. 4. 82.

${ }^{22}$ Por. Stownik ortograficzny języka polskiego, dz. cyt., s. 132. Instructions for Contributors, dz. cyt., s. 580, dopuszcza obydwie możliwości oddawania przydechu mocnego: $h \mathrm{i}$ .

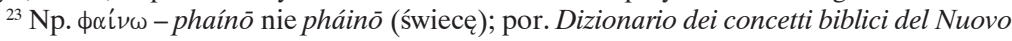
Testamento, dz. cyt.

${ }^{24}$ Por. Słownik wyrazów obcych, dz. cyt., s. V. W transkrypcji można by opuszczać akcent nad wyrazami jednosylabowymi, bo w nich nie ma problemu, którą sylabę akcentować, np. légo ten grafén, ale wtedy nie odróżniałyby się one od jednosylabowych wyrazów nie mających w ogóle akcentu, tzw. proklityk i enklityk, co w czytaniu tekstu greckiego nie jest bez znaczenia. 
Dziś autorzy najczęściej pomijają zupełnie akcenty, np. legō tēn graphēn, lego ten grafen, zaznaczając je tylko wtedy, gdy decydują o znaczeniu wyrazu, np. ${ }_{\alpha} \alpha \lambda \alpha$ - álla, álla (inne, rodz. nijaki liczba mnoga) i $\alpha \lambda \lambda \alpha$ - allá, allá (lecz),

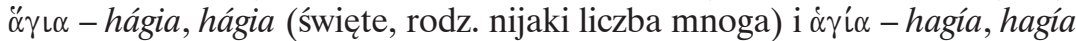
(święta, rodz. żeński liczba pojedyncza). Upraszcza to znacznie zapis, ale powoduje, że wyrazy są akcentowane niepoprawnie.

Trema ("), czyli puncta diaeresis, oznacza, że samogłoska, nad którą ten znak jest postawiony, nie tworzy dyftongu z poprzednią samogłoską. Aby uniknąć dwuznaczności, trzeba ją zaznaczyć przy ı, koniecznie w translite-

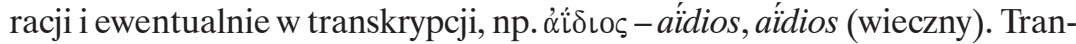

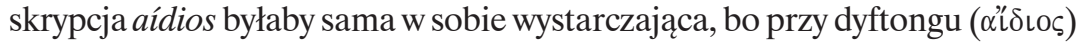
mielibyśmy zapis ájdios, ale w transliteracji dyftong ten oddalibyśmy właśnie przez aídios. Przy u tremę można pominąć, bo samogłoska ta jest inaczej zaznaczana, gdy występuje samodzielnie $(y)$, a inaczej w dyftongu $(u, t), \mathrm{np}$.

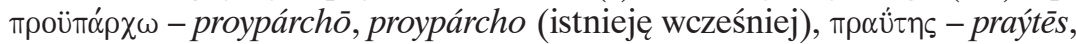
praýtes (łagodność). Bez tremy wyrazy te oddalibyśmy przez: proupárchō, prupárcho i praútēs, práttes.

Apostrof (') jest znakiem elizji (wyrzutni), której ulega samogłoska kończąca wyraz ( $\mathrm{z}$ wyjątkiem u), jeśli następny wyraz zaczyna się również od samogłoski. Zaznaczamy go tak samo jak w grece, robiąc odstęp pomiędzy

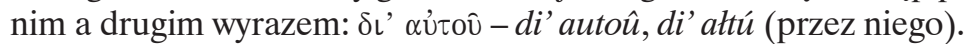

Koronis (') jest stawiany nad samogłoską, która powstała ze zlania się samogłoski końcowej jednego wyrazu z samogłoską początkową następnego wyrazu (krasis - zmieszanie). Nie zaznaczamy tego znaku ani w transliteracji,

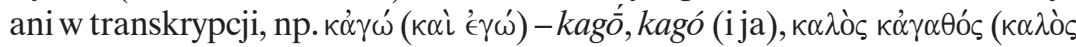

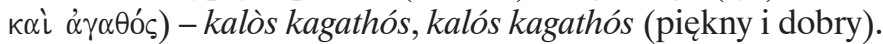

Znaki interpunkcyjne zaznaczamy w transliteracji i transkrypcji. Nie nastręczają one trudności. Grecka kropka (.) i przecinek (,) odpowiadają naszej kropce i przecinkowi. Grecki średnik (;) jest naszym znakiem zapytania (?), a podniesiona kropka (·) oznacza nasz dwukropek (:) lub średnik (;)

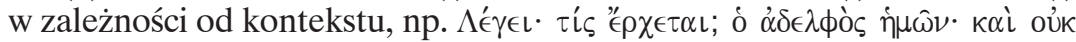

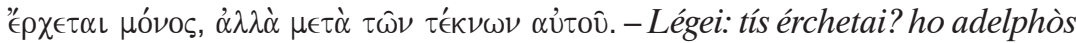
hēmôn; kaì ouk érchetai mónos, allà metà tôn téknōn autoû., Légej: tís érchetaj? ho adelfós hemón; káj uk érchetaj mónos, allá metá tón téknon attú. (Mówi: kto przychodzi? brat nasz; i nie przychodzi sam, lecz z dziećmi swymi.).

${ }^{25}$ Por. J. W. L. RosŁon, Gramatyka języka greckiego oparta na tekstach Starego a zwłaszcza Nowego Testamentu dla studentów biblistyki i nauk pokrewnych, Warszawa 1990, s. 201-203; M. BorowsKa, Морнодúкๆ. Książka do nauki języka starogreckiego, Warszawa 1996, s. 15. 24; G. SzAmocki, Greka Nowego Testamentu, dz. cyt., s. 53-54.

${ }^{26}$ Według Novum Testamentum Graece, ed. Nestle-Aland, Stuttgart ${ }^{26} 1981$. 
Liczby oznaczane są przez litery zaopatrzone w kreskę u góry z prawej strony, gdy wyrażają jednostki, dziesiątki i setki, np. $\alpha^{\prime}-1, \kappa^{\prime}-20, \tau^{\prime}-300$, $\lambda \delta^{\prime}-44, \phi \xi \eta^{\prime}-568$. Tysiące oznaczane są przez litery opatrzone kreską $z$ lewej strony, np. ` $\alpha-1000, ` \beta-2000$, ` $ı-10000$. Niektórzy stawiają kreskę u dołu:,$\alpha$. Dla trzech liczb wykorzystano znaki zapożyczone z alfabetu fenickiego (dwa pierwsze były używane jako litery w alfabecie greckim): $\varsigma$ (stigma) - 6, Q (koppa) - 90, $\rightarrow($ sampi $)-900^{25}$.

Zaproponowany system transliteracji oddaje precyzyjnie każdą literę grecką $\mathrm{i}$ inne znaki, z wyjątkiem przydechu słabego, koronis i tremy nad u (iن). System transkrypcji nie jest tak precyzyjny, pozwala jednak prawidłowo wymawiać greckie głoski. Jedyną dwuznaczność stanowi zapis au i eu, który w transliteracji oznacza dyftongi (oddawane w transkrypcji przez at, et), a w transkrypcji odrębne samogłoski (oddawane w transliteracji przez aou, eou).

\section{Przykłady}

Zobaczmy teraz na przykładach z Nowego Testamentu, w jaki sposób dokonuje się transliteracji i transkrypcji według zaproponowanego systemu. Będą to teksty: Mk 1, 1-3 i 1Kor 15, 1-2 $2^{26}$. Najpierw przedstawimy wersję pełną, a następnie nieco uproszczoną. W zależności od charakteru publikacji i możliwości drukarskich można uwzględniać wszystkie znaki greckie albo zrezygnować z oddawania niektórych z nich. Ważne jest, aby zapis był jednolity.

\section{Mk 1:}

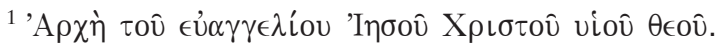

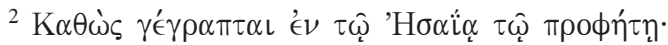

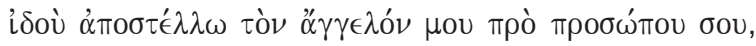

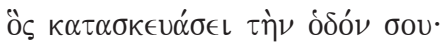

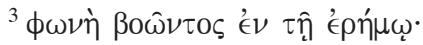

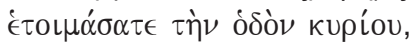

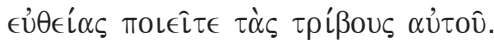

\section{Kor 15:}

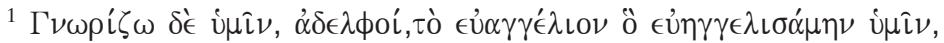

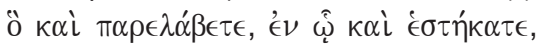

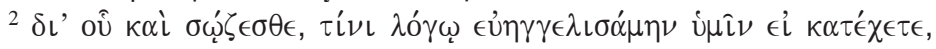

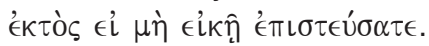


Transliteracja:

Mk 1:

${ }^{1}$ Archē toû euaggeliou Ièsoû Christoû hyioû theoû.

${ }^{2}$ Kathò̀s gégraptai en tô $\hat{E}_{i}$ saḯa ${ }_{i} \hat{o}_{i}$ prophèté $_{i}$ :

idoù apostéllō tòn ággelón mou prò prosốpou sou,

hòs kataskeuásei tè̀n hodón sou;

${ }^{3}$ phōnè boôntos en tê ${ }_{i}$ erémōo

hetoimásate tèn hodòn kyríou,

eutheías poieîte tàs tríbous autoû.

\section{Kor 15:}

${ }^{1}$ Gnōrídzō dè hymîn, adelphoí, tò euaggélion hò euēggelisámēn hymîn,

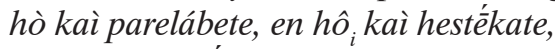

${ }^{2}$ di' hoû kaì sốdzesthe, tíni lógō euēggelisámēn hymîn ei katéchete, ektòs ei mè̀ eikê episteúsate.

Transkrypcja:

Mk 1:

${ }^{1}$ Arché tú ełangelíu Iesú Christú hyjú theú.

${ }^{2}$ Kathós gégraptaj en tó Esaïa tó proféte:

idú apostéllo tón ángelón mu pró prosópu su,

hós kataskełásej tén hodón su;

${ }^{3}$ foné boóntos en té erémo:

hetojmásate tén hodón kyríu,

etthéjas pojéjte tás tríbus attú.

\section{Kor 15:}

${ }^{1}$ Gnorídzo dé hymín, adelfój, tó ełangélion hó etengelisámen hymín, hó káj parelábete, en hó káj hestékate,

${ }^{2}$ di' hú káj sódzesthe, tíni lógo etengelisámen hymín ej katéchete, ektós ej mé ejké epistétsate.

Gdybyśmy w transliteracji opuścili akcenty i iota subscriptum, otrzymamy wtedy zapis:

Mk 1:

${ }^{1}$ Archè tou euaggeliou Ièsou Christou hyiou theou.

${ }^{2}$ Kathōs gegraptai en tō Ésaïa tō prophètē: 
idou apostellō ton aggelon mou pro prosōpou sou, hos kataskeuasei tēn hodon sou;

${ }^{3}$ phōnē boōntos en tē erēmō:

hetoimasate tēn hodon kyriou,

eutheias poieite tas tribous autou.

\section{Kor 15:}

${ }^{1}$ Gnōridzō de hymin, adelphoi, to euaggelion ho euēggelisamēn hymin, ho kai parelabete, en hō kai hestēkate,

${ }^{2}$ di' hou kai sōdzesthe, tini logō euēggelisamēn hymin ei katechete, ektos ei mē eikè episteusate.

Natomiast transkrypcja z pominięciem akcentów miałaby postać:

\section{Mk 1:}

${ }^{1}$ Arche tu euangeliu Iesu Christu hyju theu.

${ }^{2}$ Kathos gegraptaj en to Esaïa to profete:

idu apostello ton angelon mu pro prosopu su,

hos kataskełasej ten hodon su;

${ }^{3}$ fone boontos en te eremo:

hetojmasate ten hodon kyriu,

etthejas pojejte tas tribus attu.

\section{Kor 15:}

${ }^{1}$ Gnoridzo de hymin, adelfoj, to etangelion ho etengelisamen hymin, ho kaj parelabete, en ho kaj hestekate,

${ }^{2}$ di' hu kaj sodzesthe, tini logo etengelisamen hymin ej katechete, ektos ej me ejke epistetsate.

\section{Riassunto}

\section{La traslitterazione e la trascrizione dell'alfabeto greco}

Nell'articolo si propone un sistema della traslitterazione e della trascrizione dell'alfabeto greco, che viene poi spiegato sullo sfondo delle altre soluzioni e mostrato sugli esempi presi dal Nuovo Testamento. Lautore vuole offrire un aiuto a chi deve traslitterare o trascrivere un testo greco, il che accade non di rado nelle pubblicazioni bibliche, teologiche e filosofiche, perché la conversione dei caratteri greci in quelli latini sia precisa e comprensibile. Forse questa proposta potrebbe contribuire in qualche misura all'elaborazione di un sistema della traslitterazione e della trascrizione accettata e usata comunemente fra gli esegeti e teologi. 